\title{
Review
}

\section{Intervention empowerment of families in preventing and controlling overweight and obesity in children: A systematic review}

\author{
Fransiskus Geroda Mado, ${ }^{1,2}$ Saifuddin Sirajuddin, ${ }^{3}$ Masyta Muis, ${ }^{3}$ Ida Leida Maria, ${ }^{3}$ \\ Darmawansyah Darmawansyah, ${ }^{3}$ Muhammad Alwi Arifin ${ }^{3}$ \\ ${ }^{1}$ Hasanuddin University, Makassar; ${ }^{2}$ Faculty of Public Health, Nusa Cendana University, Kupang; ${ }^{3}$ Faculty of \\ Health Public, Hasanuddin University, Makassar, Indonesia
}

\begin{abstract}
There have been an increasing overweight and obesity in very anxious children. Furthermore, obesity is a condition that occurs due to the accumulation of excess or abnormal fat. This disorder is believed to be the most significant public health problem that affects children in the $21^{\text {st }}$ century. This study aimed to examine the literature review, articles and research results analyzing the effectiveness of family or parent empowerment interventions through health education. Many research articles were searched on several databases such as PubMed and PreQuest, using the following keywords which include "family empowerment", "overweight", "obesity", "health lifestyle", "BMI”, "children", "RCT" starting from 2014 to 2019. The searched results obtained 162 articles on family empowerment, overweight and obesity. Out of the 162 articles, 20 were selected that discussed family empowerment interventions for overweight and obesity. Critical analysis of the 20 articles was carried out based on design, sample, treatment, parameters, findings and conclusions. The literature review analysis showed that family empowerment interventions in the form of health education or promotion activities vary widely in terms of methods, components, duration, individuals involved, specificity and effectiveness. Furthermore, this intervention consists of training activities, courses, and teaching practices. Statistical analysis showed that all these methods significantly increased the ability and independence of the family in controlling overweight and obesity. In conclusion, health education interventions that are packaged in various programs are proven to significantly improve the ability of families or parents in preventing and controlling overweight and obesity in children.
\end{abstract}

\section{Introduction}

Overweight and obesity is a chronic mismatch between food intake and the energy expended. It is a situation whereby food consumption exceeds the normal requirements for increasing body mass indexg. ${ }^{1}$ The overweight and obesity in children increased drastically with the most recent estimates that indicate it's effect in approximately 340 million worldwide. $^{2}$ Furthermore, there have been an increasing overweight and obesity in anxious child. ${ }^{3}$ The addition of cases overweight and obesity in children occurs in all geographical areas in the world, especially for residents living in urban areas both in developed and developing countries. The world health agency reported that total number of cases obesity for children is 340 million, of which $83.3 \%$ are in developing countries. Therefore, disorders have become the center of attention of WHO. ${ }^{4} \mathrm{~A}$ foresight report on obesity on its estimated prevalence in the general population of the world and based on the current trend shows that in 2050 , $60 \%$ of men and $50 \%$ of women will suffer from obesity. ${ }^{5}$

Childhood is regarded as the most important period of life. health problems or illness that occurs during this period, would be brought to maturity or become a risk factor for the onset of diseases at adulthood. ${ }^{6}$ The growth and development of children will be disrupted due to overweigth and. However, other health problems such as psychological disorders and cognitive dysfunctions also affects their development. Abnormalities in body weigth that accur in aduults already happened in children adolescent. Furthermore, previous studies has shown that $10 \%$ of school-age children in various parts of the world are obese. ${ }^{7}$

Factors that causes obesity in children are very complex, namely biological, psychosocial, behavioral and cultural. The biopsychosocial framework for understanding obesity shows that the biological, psychosocial and behavioral factors greatly contribute to the weight status of children. These include the characteristics of the child, such as sex, age, birth weight, food intake, physical activity behavior, parenting styles and family characteristics, lifestyle, family, leisure and the environment. ${ }^{8}$

The physical and phychologi effects of obesity are very detrimental to them and has the potential of continuing into adulthood. Short-term health risks of obese children include metabolic disorders such as high blood pressure, dyslipidemia, homeostatic glucose disorders, and syndrome metabolic. ${ }^{9}$ In the

Significance for public health

Overweight and obesity are disorders that occur as a result of the accumulation of nutrients and fats which exceeds the normal body weight. The presence of this disorders in school children is a major problem because it continues into adulthood and act as risk factors for the incidence of metabolic and degenerative diseases. The Prevention and therapy of obesity in children is carried out by regulating their diet, increasing their physical activities and changing their pattern of behavior. One of the effective way of preventing overweight and obesity is through a family-based approach. Family empowerment interventions through Health Education and behavior change ultimately prevents and controls overweight and obesity. This study describes the strong relationship between family empowerment interventions and the efforts to prevent and control overweight and obesity. 
long term, obesity in children tend to settle when the age of adulthood is attained, this puts the risk of morbidity such as diabetes, cardiovascular, stroke same cancer. In the psychological context of obesity, children generally experience poor body image and low self-esteem which often develops into anxiety and depression in adulthood. ${ }^{10}$ Proactive strategies are needed when childhood has been advocated for, and this would help in prevention of overweight and obesity. ${ }^{11}$ Examples of such strategies include promoting a health diet, physical activity, and the subtraction of screen time (watching TV, playing games). This is important in preventing obesity among children in the early period of life and it was also stated in the guidelines pioneered by WHO on the prevention of obesity in children. ${ }^{12}$

The environment provides a great impact on all social, cognitive, behavioral and health aspects, including overweight and obesity. ${ }^{13}$ Intervention at an early stage when the behavior and biology of the body is relatively unchanged, is capable of preventing overweight and obesity in children. ${ }^{13}$ Furthermore, such interventions need to begin in the period of childhood, and parents have a stratergic role to play in shaping the health and healthy lifestyle of their children at an early age. ${ }^{10}$ Parents need to watch their children's weight and eating behavior and control their food intake. Furthermore, the involvement caregivers in the stages of children is reported to enhance the long-term effects of weight control interventions. ${ }^{10}$ Parents is closely related to a healthy lifestyle and choldren's behavior, family-based intervention are used to effectively prevent obesity by providing behavior changes for all family members. Theoretically, the process and results of family empowerment provide knowledge about the benefits and strategies of obesity prevention. ${ }^{14}$

The most effective way of preventing and controlling overweight and obesity is through family empowerment. Social reality context, parents of children that are overweight and obese are able are able to control the risk factors for obesity through family empowermen. In other contexts the empowerment of family and parents include the parental knowledge about nutrition, its influence on the choices and structures of food, and eating patterns. Furthermore, it also include sedentary habits such as watching $\mathrm{TV}$, movies, playing games, cellphones, and everything influential in the development of children's lifetime habits that contribute to normal weight, overweight or obesity. ${ }^{5}$ The construction of other measured empowerment of parenting self-efficacy is important in maintaining obesity-risk behaviors. It also include the beliefs of parents if promotion and health lifestyle through by parents can effectively make a difference to their children. ${ }^{15}$ The reason for choosing family empowerment interventions is because it is one of the most effective and successful methods of managing and preventing obesity in children. ${ }^{16}$

\section{Design and Methods}

Strategy the search was identified from relevant electronic databases, namely PubMed and PreQuest. The lists of reference for all relevant articles were searched simple to further identify additional studies that may exist and have not been captured by search engines. In addition, the articles sought were limited to the last 5 years. Search strategies for English-language research articles that are relevant to this research topic were carried out using the following keywords, namely "family empowerment", "overweight", "obesity", "health lifestyle", "BMI", "children", "RCT". This study analyzes family empowerment interventions to improve the ability of families in preventing and controlling overweight and obesity in children. Furthermore, the selection criteria was based on the PRISMA checklist and the study design used was RCT (randomized control trial). However, other quantitative studies (cross-sectional, laboratory-based observations, longitudinal) were not included.

\section{Results and Discussions}

In the beginning of the search, 13,056 articles were obtained (Figure 1). The proportion of articles $(n=8145)$ was excluded because it was not relevant, and 4911 articles were filtered. Most of them $(n=4751)$ were released at the time of review because they were still irrelevant. One hundred and sixty full text articles were read, while the remaining twenty- two were included in the analysis of this study because they are very relevant to the literature review and could be further analyzed. In general, the articles that were used as samples in this study were the results of a quasi-experimental design research with a pre-test and post-test control group, using the RCT approach (Table 1). The advantages of the quasy-experimental studies is that they are often carried out at the population level and not the individual level. Therefore, they are capable of covering a larger population. Quasi-experimental studies are considered more real because it shows the effectiveness of the real world and the intervention that is being implemented. ${ }^{17}$ The samples used in this study were parents, children and health workers with a total number of 1335 . Furthermore, the proportion of the sample in the intervention group was slightly more than the control group. Most of the studies did not provide intervention for the control group. From the 20 studies that have been reviewed, it was shown that majority of observations in the intervention group were always better than the control group.

The method of giving intervention was carried out with various health education programs, which include health education intervention, educational program, educational intervention, home based management, and participative health education, ${ }^{4,17-}$ ${ }^{19}$ Furthermore, the components of the intervention were training activities, courses, and teaching practices. This Health Education approach was very important. Health Education does not only increases knowledge and skills but also improves long-term health and acts as a powerful tool in promoting health justice. ${ }^{20}$ The media used in implementing the intervention include flipcharts, posters, books, and modules. The duration of administration of the research interventions varied widely, ranging from 6 weeks to 4 years. ${ }^{4,21}$ The parameters seen in the results of this study include increased ability and the family or parents independence in the prevention and control of overweight and obesity, by measuring several existing independent variables Some of the main variables in the prevention of obesity and obesity are organizations that regulate nutrition, behavior and lifestyle changes. ${ }^{22-24}$

The results of the research that were critically examined for the preparation of the literature review showed that the strategies needed to improve the ability and independence of families or parents in the prevention and control of overweight and obesity are health education and other approaches in the form of training activities, courses, teaching practices in the classroom, and using various media, such as flipcharts, posters, books, and modules. ${ }^{25-}$ 27 The socioeconomic backgrounds of families or parents are very diverse and it will greatly affect the effectiveness of prevention and control of overweight and obesity. ${ }^{28,29}$ From the 20 articles reviewed, it was shown that not all studies produced signifi- 
Table 1. A summary of the study intervention empowerment of families to prevent and control overweight and obesity in children based on RCTs.

\begin{tabular}{|c|c|c|c|c|c|}
\hline Author & Sample & Intervention & Duration & Relevant findings & Conclusion \\
\hline Small et al..$^{17}$ & $\begin{array}{l}\text { Parent-child partner }(\mathrm{n}=60) \text {. } \\
\text { Intervention group (33) } \\
\text { and control ( } 27) \text {. }\end{array}$ & $\begin{array}{l}\text { Intervention of cognitive-behavioral } \\
\text { and development of skills of the } \\
\text { elderly for the treatment or prevention } \\
\text { of obesity }\end{array}$ & 12 months & $\begin{array}{l}\text { These findings on the intervention } \\
\text { of cognitive-behavioral therapy was } \\
\text { given to parents to increase their } \\
\text { skills and ability to make modifications } \\
\text { to the environment that healthy } \\
\text { for their children. This brought about } \\
\text { both internalizing and externalizing } \\
\text { behavior in child compared } \\
\text { to the control group. }\end{array}$ & $\begin{array}{l}\text { A parent-based or parent-focused } \\
\text { obesity- care/prevention approach } \\
\text { showed a positive effect on the child's } \\
\text { anthropometrics and an important } \\
\text { impact on their behavior. }\end{array}$ \\
\hline Cao et al. ${ }^{4}$ & $\begin{array}{l}-14 \text { elementary school } \\
-7 \mathrm{SD} \text { intervention groups } \\
-7 \mathrm{SD} \text { control group. } \\
\text { There were } 1287 \text { students } \\
\text { in the treatment group } \\
\text { and } 1159 \text { in the } \\
\text { comparison group. }\end{array}$ & Health education, diet and exercise & 4 years & $\begin{array}{l}\text { Overweight and obesity in general decreased } \\
\text { from } 28.92 \% \text { in } 2011 \text { to } 24.77 \% \text { in } 2014 \\
\text { the difference was } 4.15 \% \text { in the treatment group } \\
\text { compared to a decrease of } 0.03 \% \\
\text { in the comparison group. } \\
\text { The treatment group was much less likely } \\
\text { to be overweight and obese and to experience } \\
\text { a decrease in average BMI scores than the } \\
\text { control group, especially for students } \\
\text { who were overweight or obese. }\end{array}$ & $\begin{array}{l}\text { The intervention approach targeting the } \\
\text { family-individual-school is generally able } \\
\text { to reduce overweight and obesity. }\end{array}$ \\
\hline Daniels et al. ${ }^{13}$ & $\begin{array}{l}\text { A total of } 698 \text { mothers } \\
\text { devoted extensively to the } \\
\text { health of their babies. } \\
\text { These mothers were randomly } \\
\text { given the opportunity to attend } \\
\text { age } 5 \text { years and } \\
\text { education for } 6 \text { sessions, } \\
12 \text { weeks. }\end{array}$ & Health education & 12 weeks & $\begin{array}{l}\text { Retention at } 5 \text { years of age is } 61 \% \text {. } \\
\text { For ages } 2 \text { to } 5 \text { years, treatment of mothers } \\
\text { was reported to be non responsive to inadequate } \\
\text { feeding practices on a } 6 \text { out of } 9 \text { scale. } \\
\text { At } 5 \text { years of age, there was a more appropriate } \\
\text { response to food rejection in } 7 \text { of the } 12 \text { items (F } 0.05 \text { ). } \\
\text { The anthropometric results (BMI Z-score; } p=0.06 \text { ) } \\
\text { were statistically not significant. }\end{array}$ & $\begin{array}{l}\text { A guide for anticipatory mothers about } \\
\text { supplementary feeding was reported to } \\
\text { have increased the protection against } \\
\text { feeding practices. The effect of this } \\
\text { treatment persisted until } \\
\text { was in line with the insignificant trend for } \\
\text { children who had the lowest BMI Z values } \\
\text { at each point calculated after treatment. }\end{array}$ \\
\hline
\end{tabular}

\begin{tabular}{|c|c|c|c|c|c|}
\hline Benestad et al. ${ }^{20}$ & $\begin{array}{l}37 \text { children in each group. } \\
69 \text { families }\end{array}$ & $\begin{array}{l}\text { Education healthy lifestyles, } \\
\text { family education. } \\
\text { Behaviors, motivated to } \\
\text { a healthy lifestyle }\end{array}$ & 2 years & $\begin{array}{l}\text { Half of the } 90 \text { children are women. In general, they were } \\
\text { (SD) } 9.7(1.2) \text { years old, BMI } 28.7(3.9) \mathrm{kg} / \mathrm{m}^{2} \text { and } \\
\text { SD BMI } 3.46(0.75) \text {. The children had relatively } \\
\text { small adjustment ( } 95 \% \text { CI) and increased BMI } \\
\left(-0.8(-3.5 \text { to }-0.2) \mathrm{kg} / \mathrm{m}^{2} \text { during summer camp. }\right. \\
\text { However, the decline in BMI was relatively the same } \\
(-0), 11(-0.49 \text { to } 0.05) \text {. }\end{array}$ & $\begin{array}{l}\text { The 2-year trial of the family camp care program } \\
\text { showed relatively similar results for BMI SDS of } \\
\text { severely obese children with the usual outpatient } \\
\text { care measures for families. }\end{array}$ \\
\hline Stern et al.22 & 66 caregivers & $\begin{array}{l}\text { NOURISH-T intervention. } \\
\text { Health education and } \\
\text { skill competence }\end{array}$ & 16 weeks & $\begin{array}{l}\text { The results showed that the feasibility and effectiveness } \\
\text { of the intervention were compared to the control group. }\end{array}$ & $\begin{array}{l}\text { Most pediatric cancer patients survived } \\
\text { into adulthood, but were at increased risk of } \\
\text { weight gain and decreased PA. }\end{array}$ \\
\hline Wu et al. ${ }^{21}$ & $\begin{array}{l}623 \text { children and } \\
\text { adolescents that are obese } \\
\text { and overweight } \\
\text { (393 interventions } \\
\text { and } 230 \text { controls). }\end{array}$ & $\begin{array}{l}\text { Intervention: } \\
\text { Soccer } \\
\text { Training in aerobic } \\
\text { Endurance training } \\
\text { Combination }\end{array}$ & $\begin{array}{l}12 \text { weeks to } \\
6 \text { months }\end{array}$ & $\begin{array}{l}\text { The results showed that PA was generally associated } \\
\text { with improved CRP levels (mean difference) } \\
\text { - } 0.45 \mathrm{mg} /, \mathrm{p}=0.02 \text { ) in overweight or obese children } \\
\text { and adolescents. From } 115 \text { adolescents who are } \\
\text { overweight and obese, it was found that the PA } \\
\text { results did not significantly reduce IL-6 levels. } \\
\text { In addition, meta-regression analysis showed } \\
\text { a statistical association between CPR rates } \\
\text { and changes in BMI. }\end{array}$ & $\begin{array}{l}\text { Physical activity was associated with a very large } \\
\text { reduction in CRP concentrations, but there was no } \\
\text { significant association with IL- } 6 \text { or TNF- } \alpha \\
\text { obesity/overweight children. However, there is a } \\
\text { tendency to decrease IL-6. }\end{array}$ \\
\hline Warschburge et al. ${ }^{10}$ & $\begin{array}{l}\text { Parents of obese children } \\
\text { ( } \mathrm{n}=686 ; 7-13 \text { years) }\end{array}$ & Health education and skills & 6-12 months & $\begin{array}{l}\text { Significant reduction in intervention groups from } 0.24 \\
\text { ( } 95 \% \text { CI } 0.18 \text { to 0.30) BMI-SDS points from initial } \\
\text { hospitalization until the first year. However, } \\
\text { there was no difference at the one-year follow-up } \\
\text { (average difference } 0.02 ; 95 \% \text { CI }-0.04 \text { to 0.07). }\end{array}$ & $\begin{array}{l}\text { Care and hospitalization proved to be very } \\
\text { effective, additional training in the elderly do not } \\
\text { produce better results in the maintenance of } \\
\text { weight loss in the long term. }\end{array}$ \\
\hline Warketin et al ${ }^{23}$ & $\begin{array}{l}98 \text { children } \\
49 \text { intervention groups } \\
49 \text { controls }\end{array}$ & $\begin{array}{l}\text { Intervention } \\
\text { Physical activity }\end{array}$ & 10 months & $\begin{array}{l}\text { Prior to the physical activity intervention, } 85.7 \% \text { of } \\
\text { he children in the treatment group occupied the } 95^{\text {th }} \\
\text { / over percentile position for hypertension. } \\
\text { At the end of the study there was a tremendous } \\
\text { decrease where this value became } 16.13 \% \\
(\mathrm{p}=0.001) \text {. }\end{array}$ & $\begin{array}{l}\text { Obesity in children will increase the potential } \\
\text { for hypertension. To prevent this can be } \\
\text { through physical activity and nutrition } \\
\text { regulation. One effective way to measure } \\
\text { blood pressure is to use percentiles, } \\
\text { according to age, weight and height. }\end{array}$ \\
\hline
\end{tabular}

Continue to the next page. 
Table 1. Continued from previous page.

\begin{tabular}{|c|c|c|c|c|c|}
\hline Author & Sample & Intervention & Duration & Relevant findings & Conclusion \\
\hline Wen et al. ${ }^{12}$ & $\begin{array}{l}\text { The trial took } 1155 \\
\text { mothers during } \\
\text { the third trimester } \\
\text { of pregnancy. } \\
\text { Parallel RCTs } \\
\text { with the number } \\
\text { of mother-child } \\
\text { pairs expected }\end{array}$ & $\begin{array}{l}\text { Health education } \\
\text { through telephone } \\
\text { and SMS }\end{array}$ & 24 months & $\begin{array}{l}\text { Support for a combination approach } \\
\text { between telephone and SMS interventions } \\
\text { is a new model that is estimated to produce } \\
\text { better results as well as lower costs and wider coverage. }\end{array}$ & $\begin{array}{l}\text { The telephone and SMS approach is a new and } \\
\text { effective approach. }\end{array}$ \\
\hline Larsen et al. ${ }^{11}$ & 8 doctors, 6 nurses & $\begin{array}{l}\text { Health education, } \\
\text { prevention and motivation } \\
\text { for diet, physical activity, } \\
\text { healthy lifestyle }\end{array}$ & $\begin{array}{l}60-70 \text { min for } \\
\text { each FGD }\end{array}$ & $\begin{array}{l}\text { They recognize that overweight management during } \\
\text { hildhood was a complex task that requires evidence-based } \\
\text { cstrategies with the possibility of supervision. } \\
\text { Health experts had issues in overcoming overweight } \\
\text { in children. However, increasing awareness of obesity } \\
\text { in childhood and the consequences in the society are } \\
\text { considered useful in knowing the best way } \\
\text { to overcome this problem. }\end{array}$ & $\begin{array}{l}\text { Health professionals in general practice } \\
\text { recognize that they have obligations, } \\
\text { capacities, and special roles in the management } \\
\text { of obesity in childhood. The implementation of } \\
\text { future management programs must overcome } \\
\text { obstacles outside the evidence-based } \\
\text { standard strategy. }\end{array}$ \\
\hline Resnicow et al. ${ }^{18}$ & $\begin{array}{l}42 \text { practitioners } \\
645 \text { patients }\end{array}$ & $\begin{array}{l}\text { Health education } \\
\text { for parents. } \\
\text { Short interview } \\
\text { and motivation }\end{array}$ & 2 years & $\begin{array}{l}\text { At the 2-year follow-up, the adjusted BMI percentiles } \\
\text { were 90.3,88.1, and 87.1 for groups 1,2, and 3, respectively. } \\
\text { In general, better results were found in group } 3(\mathrm{p}=0.02) \\
\text { compared to group 1. For all groups, namely 1.2, and } 3 \\
\text { the mean change from the baseline percentile body } \\
\text { mass index was 1.8. 3,8 and 4,9. }\end{array}$ & $\begin{array}{l}\text { MI given by the provider and RD (group 3) } \\
\text { resulted in a statistically significant } \\
\text { reduction in the percentage of BMI. }\end{array}$ \\
\hline Döring et al. ${ }^{19}$ & $\begin{array}{l}1355 \text { families with } \\
1349 \text { babies }\end{array}$ & Health education and skills & 39 months old & $\begin{array}{l}\text { There were no statistically significant difference } \\
\text { in the children's BMI ( = }-0.11,95 \% \text { confidence interval } \\
\text { [CI]:-0.31 to 0.08), waist circumference } \\
(=-0.48, \text { CI } 95 \% \text { : }-0.99 \text { to } 0.04 \text { ), and the prevalence } \\
\text { of being overweight (relative risk = } 0.95,95 \% \text { CI: } 0.69-1.32) \text {. } \\
\text { No significant intervention effect was observed in the } \\
\text { maternal anthropometric data or regarding the child's } \\
\text { physical activity habits. There was a small intervention } \\
\text { effect in terms of healthy food habits among } \\
\text { children and mothers. }\end{array}$ & $\begin{array}{l}\text { There were no significant group difference in } \\
\text { children and mothers anthropometric data and } \\
\text { physical activity habits. However, there was } \\
\text { some evidence to suggest healthier food habits, } \\
\text { but it needs to be interpreted with caution. }\end{array}$ \\
\hline Pakpour et al.? & $\begin{array}{l}409 \text { Iranian adolescents } \\
\text { (age range } 14-18 \text { years) } \\
\text { were randomly assigned } \\
\text { to the parent-supported } \\
\text { MI treatment (MI + PI) } \\
\text { including assessment only } \\
\text { (passive control). }\end{array}$ & $\begin{array}{l}\text { Intervention, Diet with } \\
\text { a balanced nutritional } \\
\text { menu and physical activity }\end{array}$ & 12 months & $\begin{array}{l}\text { Against these parameters we found better results for } \\
\text { most of the outcome parameters for MI + PI } \\
\text { (eg, mean score of } 6 \text { SD BMI: } 2.58 .60 .61 \text { ) than the passive } \\
\text { comparison group. The results of anthropometry, } \\
\text { biochemistry, psychometry and behavior also explain } \\
\text { the same thing. }\end{array}$ & $\begin{array}{l}\text { In controlling obesity, MI approach which is fully } \\
\text { supported by parents is a powerful method and } \\
\text { has a positive effect. These results can be an } \\
\text { important reference in regulating MI at the } \\
\text { school level. }\end{array}$ \\
\hline William et al. ${ }^{25}$ & $\begin{array}{l}229 \text { families and } \\
251 \text { children }\end{array}$ & $\begin{array}{l}\text { Health education for diet, } \\
\text { care and physical activity }\end{array}$ & 6 months & $\begin{array}{l}\text { There are } 78 \% \text { of families who are willing to become } \\
\text { respondents where there are } 92 \% \text { of mothers and } 79 \% \\
\text { of children aged 2-9 years who attend at least one session. } \\
\text { Most of the families ( } 69 \% \text { ) took this program seriously. }\end{array}$ & $\begin{array}{l}\text { Substantially, it is necessary to know methods } \\
\text { to involve disadvantaged families who have } \\
\text { a high potential for obesity in childhood. } \\
\text { Understanding different sources of reference } \\
\text { and parents' readiness for change can } \\
\text { help in tailoring program content }\end{array}$ \\
\hline Robertson et al. ${ }^{28}$ & 120 families & $\begin{array}{l}\text { Health education, } \\
\text { lifestyle changes, } \\
\text { parenting }\end{array}$ & 10 weeks & $\begin{array}{l}\text { There were } 115 \text { families or } 128 \text { children who took part in } \\
\text { the FFH program, which was taken randomly. } \\
\text { The results showed that the } 12 \text {-month body mass } \\
\text { index } z \text {-score }(0.114,95 \% \text { Cl-0.001 to 0.229. } \mathrm{p}=0.053 \text {; } \\
\mathrm{p}=0.026 \text { and referring to UC showed insignificant } \\
\text { differences. In the economic context explaining the larger } \\
\text { average cost at FFH compared with UC, the difference } \\
\text { was roughly ( } ₫ 998 \text { vs } £ 548, \mathrm{p}<0.001) \text {. }\end{array}$ & $\begin{array}{l}\text { Economically, UC is more efficient than FFH } \\
\text { when it comes to controlling obesity. }\end{array}$ \\
\hline Buscemia et al. ${ }^{29}$ & 362 participants & $\begin{array}{l}\text { Health education; } \\
\text { nutrition and physical } \\
\text { activity }\end{array}$ & $\begin{array}{l}\text { Intervention } \\
\text { (14 weeks) } \\
\text { and follow-up of } 1 \\
\text { and } 2 \text { years }\end{array}$ & $\begin{array}{l}\text { There was retention in several time periods ie for } \\
14 \text { weeks the retention was } 89 \% \text {, for a duration } \\
\text { of } 1 \text { year the retention was } 71 \% \text {, while for a follow-up } \\
\text { of } 2 \text { years the retention was } 73 \% \text {. Furthermore, } \\
\text { the intervention with this method, for } 14 \text { weeks } \\
\text { the participants completed the assessment } \\
\text { by } 95 \% \text { and for } 1 \text { year by } 88 \% \text {. Other retention } \\
\text { outcomes of } 91 \% \text { and } 89 \% \text { for the } 12 \text { and } \\
18 \text { month periods were clearly demonstrated } \\
\text { in the third study. }\end{array}$ & $\begin{array}{l}\text { Retention of success requires adequate input, } \\
\text { including rational resource improvement, } \\
\text { planning systems, experience and flexibility. }\end{array}$ \\
\hline
\end{tabular}


Table 1. Continued from previous page.

\begin{tabular}{|c|c|c|c|c|c|}
\hline Author & Sample & Intervention & Duration & Relevant findings & Conclusion \\
\hline Karmal et $a . .^{26}$ & 50 parents and children & $\begin{array}{l}\text { Health education } \\
\text { and training }\end{array}$ & 3 months & $\begin{array}{l}\text { When compared to only providing education, } \\
\text { it is clear that there is a big difference in providing } \\
\text { education plus intervention. }\end{array}$ & $\begin{array}{l}\text { Given that the parent is in control of the } \\
\text { behavior, physical activity and nutrition of their } \\
\text { children, interventions that supports their } \\
\text { healthy choices should be explored and promoted. }\end{array}$ \\
\hline Jurkowski et al. $^{14}$ & $\begin{array}{l}\text { All parents of } 423 \\
\text { children } \\
\text { (ages 2-5 years) }\end{array}$ & Training & 10 months & $\begin{array}{l}\text { Compared with before the intervention, there was a big } \\
\text { change in the empowerment of resources for parents } \\
\text { in the follow-up phase, including children's weight } \\
(\mathrm{t}=3,235, \mathrm{p}<0.01) \text {, physical activity }(\mathrm{t}=4.459, \mathrm{p}<0.001) \text {, } \\
\text { and diet }(\mathrm{t}=4.04, \mathrm{p}<0.001) \text {. Children's screen time } \\
(\mathrm{t}=2.049, \mathrm{p}<0.05) \text { was well controlled with appreciable } \\
\text { changes in parental self-efficacy. }\end{array}$ & $\begin{array}{l}\text { The results of the pilot study of CHL are reported } \\
\text { to provide evidence of its feasibility and in the } \\
\text { context of preventing obesity it can shift the target } \\
\text { to low-income families. Interventions need to be } \\
\text { fully supported by parents while still considering } \\
\text { the socio-ecological situation. }\end{array}$ \\
\hline Taylor et al..$^{24}$ & 686 pregnant women & $\begin{array}{l}\text { Health education, } \\
\text { promotion of } \\
\text { breastfeeding, } \\
\text { healthy eating, physical } \\
\text { activity }\end{array}$ & 6-24 months & $\begin{array}{l}\text { After } 24 \text { months of intervention there was little } \\
\text { effect on body mass index ( } \mathrm{p}=0.086) \text {. However, there was } \\
\text { an effect on the group as a whole ( } \mathrm{p}=0.027) \text {. } \\
\text { An exploratory analysis of "sleep intervention" showed a } \\
\text { positive effect on obesity compared with sleep and } \\
\text { combined with FAB and comparison: OR 0.54. }\end{array}$ & $\begin{array}{l}\text { Nutrition intervention and management do not } \\
\text { appear to have an impact on changes in children's } \\
\text { body weight }\end{array}$ \\
\hline Fagg et al. ${ }^{27}$ & 298 children & $\begin{array}{l}\text { Education, vocational } \\
\text { training and } \\
\text { increased motivation. }\end{array}$ & $6-12$ months & $\begin{array}{l}\text { The MEND program starts with children who are more } \\
\text { obese than overweight, excluding obesity, women, } \\
\text { Asian, from single-parent families, living in less conducive } \\
\text { socio-economic conditions, living in cities rather than } \\
\text { rural areas. 'Normal' levels of psychological stress, } \\
\text { are boys with single parents, live in less favorable } \\
\text { socioeconomic conditions, and have participated } \\
\text { in relatively large groups of MEND programs, } \\
\text { or where administrators run more programs. }\end{array}$ & $\begin{array}{l}\text { The terms or take of MEND are unlikely to be } \\
\text { compromised. Even though its existence will help } \\
\text { strengthen the involvement of marginalized groups. } \\
\text { However, this was reduced due to the completion } \\
\text { of the program for those living in disadvantaged } \\
\text { socio-economic conditions. }\end{array}$ \\
\hline
\end{tabular}

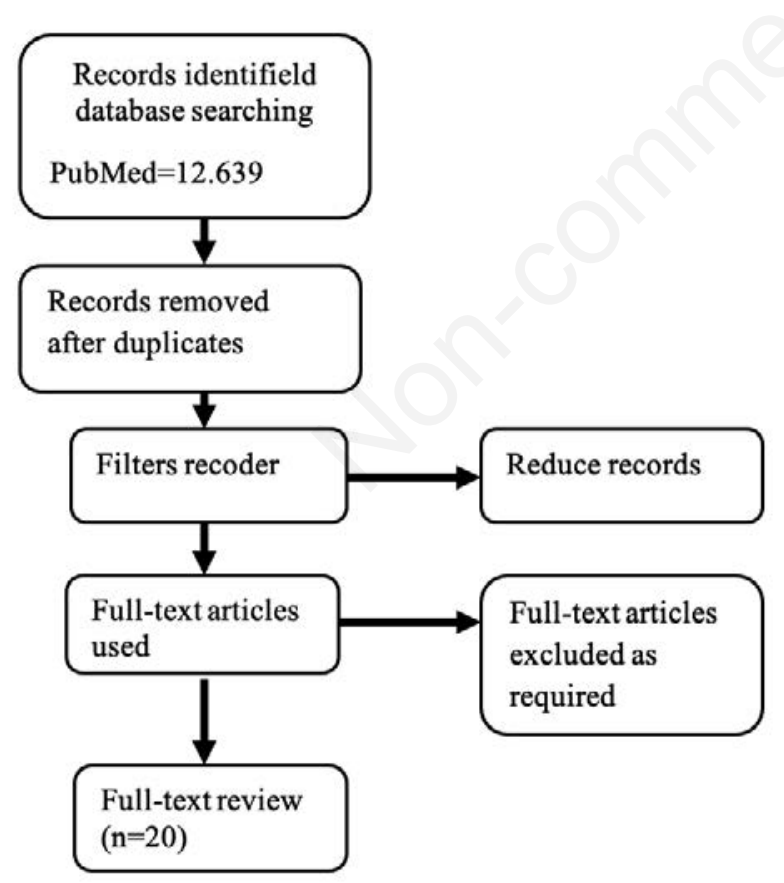

Figure 1. Prisma flowchart. cant values on all parameters measured. Through family empowerment, parents or related stakeholders could optimize the health education program by modifying the methods of providing interventions and the media used, and relevant stakeholders to achieve optimal results.

Based on the analysis of the 20 articles, the participative Health Education method was recommended to be applied in all families in order to prevent overweight and obesity. This intervention has several advantages, which include 1) it occurred in a smaller scope such as the family level for it to be more effective, 2) the pattern of intervention could be flexible according to the situation of each household, 3) the media used varies greatly, and $4)$ the duration of the intervention was quite long ( \pm 6 months) in order to guarantee the resistance of health behavior in the community.

\section{Conclusions}

Health education intervention activities that are packaged in various programs are proven to have an effect in increasing the ability of families or parents to significantly prevent and control overweight and obesity. 
Correspondence: Fransiskus Geroda Mado, Public Health Faculty Hasanuddin University, Jl. Perintis Kemerdekaan KM. 10 Makassar 90245, Indonesia.

Tel.: +62411585658 - Fax: +624115856013

Email: madofg19k@student.unhas.ac.id

Acknowledgment: The author is grateful to the Faculty of Public Health, Hasanuddin University, Makassar, Indonesia for their support and motivation during the writing of this article.

Key words: Family empowerment; health education; overweight; obesity; childhood.

Contributions: The authors contributed equally in this study.

Conflict of interest: The author declares no potential conflict of interest.

Conference presentation: Part of this study was presented at the $1^{\text {st }}$ International Nursing and Health Sciences Symposium, November $13^{\text {th }}$ to $15^{\text {th }} 2020$, Brawijaya University, Malang, Indonesia.

Received for publication: 20 January 2021.

Accepted for publication: 15 March 2021.

(C) Copyright: the Author(s), 2021

Licensee PAGEPress, Italy

Journal of Public Health Research 2021;10:2185

doi:10.4081/jphr.2021.2185

This work is licensed under a Creative Commons Attribution

NonCommercial 4.0 License (CC BY-NC 4.0).

\section{References}

1. Shloim N, Edelson LR, Martin N, et al. Parenting styles, feeding styles, feeding practices, and weight status in 4-12 year-old children: A systematic review of the literature. Front Psychol 2015;6:1849.

2. Reilly KC, Briatico D, Irwin JD, et al. Participants' perceptions of "C.H.A.M.P. families": A parent-focused intervention targeting paediatric overweight and obesity. Int J Environ Res Public Health 2019;16:2171.

3. Mwaikambo SA, Leyna GH, Killewo J, et al. Why are primary school children overweight and obese? A cross sectional study undertaken in Kinondoni district, Dar-es-salaam. BMC Public Health 2015;15:1-10.

4. Cao Z, Wang S, Chen Y. A Randomized trial of multiple interventions for childhood obesity in China. Am J Prev Med. 2015;48:552-60.

5. Lloyd J, Wyatt K. The Healthy Lifestyles Programme (HeLP) - An overview of and recommendations arising from the conceptualisation and development of an innovative approach to promoting healthy lifestyles for children and their families. Int J Environ Res Public Health 2015;12:1050-3.

6. Zhai L, Dong Y, Bai Y, et al. Trends in obesity, overweight, and malnutrition among children and adolescents in Shenyang, China in 2010 and 2014: a multiple cross-sectional study. BMC Public Health 2017;17:1-7.

7. Pakpour AH, Gellert P, Dombrowski SU, et al. Motivational interviewing with parents for obesity: An RCT. Pediatrics 2015;135:e644-52.

8. Soskolne V, Cohen-Dar M, Obeid S, et al. Risk and protective factors for child overweight/obesity among low socio-economic populations in Israel: A cross sectional study. Front
Endocrinol (Lausanne) 2018;9:456.

9. Nasreddine L, Hwalla N, Saliba A, et al. Prevalence and correlates of preschool overweight and obesity amidst the nutrition transition: Findings from a national cross-sectional study in Lebanon. Nutrients 2017;9:266.

10. Warschburger P, Kroeller K, Haerting J, et al. Empowering Parents of Obese Children (EPOC): A randomized controlled trial on additional long-term weight effects of parent training. Appetite 2016;103:148-56.

11. Larsen LM, Ledderer L, Jarbøl DE. Management of overweight during childhood: A focus group study on health professionals' experiences in general practice. Int J Family Med 2015;2015:248985.

12. Wen LM, Rissel $\mathrm{C}, \mathrm{Xu} \mathrm{H}$, et al. Linking two randomised controlled trials for healthy beginnings: optimising early obesity prevention programs for children under 3 years. BMC Public Health 2019;19:739.

13. Daniels LA, Mallan KM, Nicholson JM, et al. An early feeding practices intervention for obesity prevention. Pediatrics 2019;136:e40-9.

14. Iii W, Davison KK. The empowerment of low-income parents engaged in a childhood obesity PubMed Commons. Fam Community Health 2014;37:104-18.

15. Lim J, Davison KK, Jurkowski JM, et al. Correlates of resource empowerment among parents of children with overweight or obesity. Child Obes 2017;13:63-71.

16. Adamo KB, Brett KE. Parental perceptions and childhood dietary quality. Matern Child Health J 2014;18:978-95.

17. Small L, Ii LT, Aldrich H, et al. A pilot intervention designed to address behavioral factors that place overweight/Obese young children at risk for later-life obesity. West J Nurs Res 2017;39:1192-12.

18. Resnicow K, McMaster F, Bocian A, et al. Motivational interviewing and dietary counseling for obesity in primary care: an RCT. Pediatrics 2015;135:649-57.

19. Döring N, Ghaderi A, Bohman B, et al. Motivational interviewing to prevent childhood obesity: A cluster RCT. Pediatrics 2016;137:e20153104

20. Benestad B, Lekhal S, Småstuen MC, et al. Camp-based family treatment of childhood obesity: randomised controlled trial. Arch Dis Child 2017;102:303-10.

21. Wu S, Ding Y, Wu F, et al. Socio-economic position as an intervention against overweight and obesity in children: A systematic review and meta-analysis. Sci Rep 2015;5:11354.

22. Stern M, Ewing L, Davila E, et al. Design and rationale for NOURISH-T : A randomized control trial targeting parents of overweight children off cancer treatment. Contemp Clin Trials 2015;41:227-37.

23. Warkentin S, Mais LA, Latorre MDRDDO, et al. Relationships between parent feeding behaviors and parent and child characteristics in Brazilian preschoolers: A cross-sectional study. BMC Public Health 2018;18:1-11.

24. Taylor BJ, Gray AR, Hons B, et al. Targeting sleep, food, and activity in infants for obesity prevention: An RCT. Pediatrics 2017;139:e20162037.

25. Williams SL, Lippevelde W Van, Magarey A, et al. Parent engagement and attendance in PEACH TM QLD - an up-scaled parent-led childhood obesity program. BMC Public Health 2017; 17:559.

26. Karmali S, Ng V, Battram D, et al. Coaching and/or education intervention for parents with overweight/obesity and their children: Study protocol of a single-centre randomized controlled trial. BMC Public Health 2019;19:1-12.

27. Fagg J, Cole TJ, Cummins S, et al. After the RCT: who comes 
to a family-based intervention for childhood overweight or obesity when it is implemented at scale in the community? J Epidemiol Community Health 2015;69:142-8.

28. Robertson W, Fleming J, Kamal A, et al. Randomised controlled trial and economic evaluation of the 'Families for
Health' programme to reduce obesity in children. Arch Dis Child 2017;102:416-26.

29. Buscemi J, Blumstein L, Kong A, et al. Retaining traditionally hard to reach participants: lessons learned from three childhood obesity studies. Contemp Clin Trials 2015;42:98-104. 